\title{
Ottoman Institutions and Legal Regulations in 19th Century Bulgarian Economy; A Review Based on Institutional Economics ${ }^{1}$
}

Received: 30.04 .2021

Available online: 29.09 .2021

\section{Mustafa Can Güripek \\ Şevket Kamil Akar*}

\section{Abstract}

In the 19th century, developments took place in many areas around the world. The industrialization process has accelerated in the world, production scales have increased, and the economic integration process has started. With the globalization of trade, the boundaries became less visible, and entrepreneurs could trade freely in different parts of the world. In this article, the extent to which the economic activities on the Bulgarian territory could be integrated into the world trade in the 19th century, the political and financial institutions of the Ottoman Empire, and the legal arrangements that affected the welfare of the Bulgarian people will be discussed. In making this discussion, the basis of institutional economic thought will be examined, and the effects of the institutions of the Ottoman Empire on the economic structure of Bulgaria will be reviewed. Did the Ottoman Empire, expressed in the terms of institutional economics, constitute inclusive institutions or exploitative institutions in economic activities on the territory of Bulgaria? This discussion will be more explanatory under four main headings. These are; traditional institutions, tax regulations, financial institutions, and legal regulations. Thus, the effects of the Ottoman Empire on the economic structure in the territory of Bulgaria will become more pronounced.

Keywords: Ottoman Empire, Bulgarian Economic Structure, Institutions, Law Regulations, Tax Regulations

JEL: N 20, N 23, N 40, N 43

\section{Introduction}

In this article economic activities on the territory of Bulgaria under the Ottoman Empire in the 19th century will be examined. This review will be conducted under four headings. These headings are formed within the framework of the primary institutions shaped and put forward by the theory of institutional economics. Under the headings identified as traditional institutions tax regulations, financial institutions, and legal regulations, the economic structure of the Ottoman Empire in Bulgaria will be discussed. Before starting the investigation under these headings, it will be useful to explain what

\footnotetext{
1 This article was supported by BAP Project Application affiliated to Istanbul University.

* Istanbul University, Faculty of Economics, Economic History, Research Assistant.

"Istanbul University, Faculty of Economics, Economic History, Assist.Prof. Dr.
} 


\section{Articles}

reasoning lines are selected. After examining the theoretical background of institutional economics in the introduction, we can start to explore the Ottoman institutions.

In explaining the different levels of prosperity of the two countries or regions, institutional economics exposes the lack of classical economic thought. Neoclassical and classical economic theory assumes that there is a market-oriented economy. Accordingly, consumers, producers, firms, and households measure financial performance by analysis. However, institutional economics says such a review is minimal. According to institutional economics, the type of production a firm is in depends on many different factors such as the developments in the history of production, the legal basis of producers and consumers, the social environment of the employees, and the existing structures of traditional institutions. Thus the rate of disclosure of the economy increases (Simon, 1997).

Even if macro factors such as geography, climate, and population are the same in two regions or in neighboring countries, there may be significant differences in their economic development. For example, it can be seen that when the same agricultural technique is applied to soils with the same productivity, the production outputs are different. This leads to the question of why different levels of production have occurred, even though similar methods have been applied in China, India, and Europe over the centuries. Institutional economics says that differences in social structure, as well as the material structure, should be examined. In other words, the role of social entities in these production processes needs to be revealed (Polanyi, 2001).

In other words, when analyzing economic change and welfare levels, all changes in culture thought structure, belief system, legal
Ottoman Institutions and Legal Regulations in 19th Century Bulgarian Economy

structure, and political and social structure should be considered. Douglass C. North, one of the leading figures of institutional economics, explains the reasons for the superiority of the Western world over the East and says that with the change of the physical environment of the West, social thinking has also adapted to it. He states that the West has succeeded in creating institutional and organizational change, and thanks to the legal ground established, institutions are working more creatively and efficiently (North, 2005). In other words, the change in the physical environment integrates with the social structure through protection and justice. The combination of many factors, such as traditions, customs, forms of communication, habits, formal and informal rules, plays a role in economic development (North, 1990).

In addition to many factors such as tradition, culture, communication, etc., the legal structure is one of the factors that the institutional economy insists on. Economic theory and practice may not always be the same. In some cases, informal rules may have been formed in practice by ignoring legal rules. Or it may take time for the solutions needed to regulate a practical problem in the law. But ultimately, it can be said that legal regulations directly affect the functioning of the economy. Although many names such as agricultural communities, early producers, feudal lords, guilds, entrepreneurs, businessmen, and fabricators have changed, the legal basis has defined the boundaries of these producers. In some cases, the legal structure prevented the development of economic activities, imposed restrictions on them, and in some cases, encouraged the producer to change the economic structure (Commons, 1925). If the legal structure is regulated encouragingly, the rules on property rights and patents 


\section{Articles}

are clearly articulated. Thus, the efficiency and rationality of the institutions increase (Hodgson, 2007).

After giving the necessary theoretical background, one needs to make a final distinction. This distinction divides institutions according to their effects on the economic structure, inclusive institutions, and exploitative institutions. Inclusive institutions create inclusive markets that offer people the freedom to work in the most appropriate professions according to their abilities and provide similar conditions. It provides the environment for two critical institutions, such as technology and education, which affect welfare. Inclusive institutions increase welfare and protect property rights. Exploiting economic institutions,arise as a result of the political authority's willingness to cooperate with a specific group to manage the economy from a single center. Elite groups, through political power, share the prosperity that belongs to the majority of society. In economies dominated by these institutions, incentives and property rights are limited. Creative thinking and economic change cannot occur (Acemoğlu \& Robinson, 2013).

Now the economic structure on the territory of Bulgaria under the administration of the Ottoman Empire can be examined in terms of this theoretical structure. First of all, it will be necessary to discuss the role of traditional Ottoman institutions in the economic formation of Bulgaria and whether they are inclusive or exploitative.

\section{The Place of Traditional Ottoman Institutions in the 19th Century Economic Structure of Bulgaria}

In this section, the role of the Ottoman institutions in the economic structure of the Bulgarian territory, whether inclusive or exploitative institutions, will be discussed. If we say that while Bulgaria was entering the 20th century, it had problems in its economic development because it was a new and young state, we would be ignoring some of the problems. Ottoman institutions affecting the economic development level of Bulgaria should be examined carefully. Pencho Penchev also argues that the Bulgarian War of Liberation in 1878 did not cause poverty, but that the war was the result of the economic situation. (ПенчеВ, 2008) For this reason, traditional institutions in the Ottoman period should be examined. Traditional institutions and the situations caused by their disappearance will be interpreted. The first of these traditional institutions is the classical guild system.

\subsection{Guilds}

The guilds operating in the Ottoman Empire were organized on the basis of their own business. The state did not want to produce more goods than those needed to regulate the economic life, supervising and limiting the trades that would provide it through guilds. In a period when the boundaries between the city and the countryside were not lifted, and international trade was not very useful, it controlled the economy by limiting the number of shops (breaches) to be opened. (İnalcık, 2013).

The most important tool used by the Ottoman Empire in controlling the economy was the "ihtisap Kanunları". "Ihtisap Kanunları" set necessary conditions such as the price and quality of goods in the market. In determining and supervising these, the state authority cooperated with the guilds. (Genç, 2013) A similar practice of 'justice price' in Europe was included in the Ottoman Special Laws called 'narh'. In Narh implementation, which is defined as the upper limit determined by 


\section{Articles}

the state in the prices of goods and services, the profit range ranged from $5 \%$ to $15 \%$. Penal severe sanctions would be imposed on those who did not comply with these rates and wished to make more profits. (Kütükoğlu, 1983) With narh implementation, an attempt was made to prevent price fluctuations and price increases in the market, and attention was given to delivering the products in the market to people. (Pamuk, 2014) In short, with the rules set by the state in the Ottoman Empire, it not only maintained its consumer position but also used guilds to control the producers. Under the specialization laws, the producer made his authority and secured the guilds by providing economic gain. (İnalcık, 2013) In another important study, the price surveys made in Ruse, Vidin, Sofia, and Dobrich provinces between 1650-1820 were evaluated through official documents. It has been determined that the price movements in these four provinces are representative. (Atanasov, 2014) This study draws attention in terms of understanding how the narh practice took shape in the modernizing world.

However, these institutions and doctrines, which had an essential place in the classical period of the Ottoman Empire, could not find a place in the modernizing world. The guild was restrictive in the activities and teachings of increased international trade, liberalization in the world, increasing population, product differentiation, and most importantly, industrybased mass production.

We have a precious work by Nikolay Todorov. In the 19th century, Todorov examined the guilds of merchants in Plovdiv, where Samakov and Kotel developed rapidly and claimed that the guilds showed resistance to capitalist development. As mentioned above, only the members of the guild could ensure production, depending on the guild
Ottoman Institutions and Legal Regulations in 19th Century Bulgarian Economy

registered craftsman, naturally built an elite group, even in the fastest growing sector of the period, such as abacılık. (Todorov, 2011) Todorov says that an organization like the guild created elites even within itself and that some guild members used large amounts of credit from the common money in the guild, thus making serious profits.

The Gumusgerdan family, which would later take part in the Ottoman parliament, was also part of these guilds. The Gumusgerdan family supplied the fabric for the army. The Gumusgerdans, the state's abacıbaşı, thus established a factory. (Lybertaros, 2015) As they will be explained below, they even gained positions at important levels of the state and started to collect taxes on behalf of the state.

Of course, it is difficult to make definitive judgments about historical processes. However, we need to locate the guild institution in a place to study it from the point of view of institutional economics. Given that in a more integrated, internationally marketed, and industrialized world, guilds only serve certain interest groups, guilds fall into the category of exploitative economic institutions.

\subsection{Deterioration, Abolition of the Janissary Army}

In the modernizing world, economic activities wanted a secure political basis. Due to social unrest and insecurity economic activities were limited. In the classical period of the Ottoman Empire, Pax Ottoman, this order and the necessary institutions for development had successfully been established. However, these traditional institutions had lost their essence in the 19th century and had lost their meaning. In this subheading, the impact of the janissary class, which constitutes an integral part of the Ottoman military power, on the 


\section{Articles}

economic activities on the territory of Bulgaria will be discussed.

In the war in 1792, there were 120,000 soldiers in the Ottoman army while the Russian army had only 8,000 soldiers. Nevertheless, the Russians had achieved a decisive victory against the Ottomans. This was an event that warned the Ottoman Empire to make serious reforms in the military field. In a meeting held by the Ottoman administration, everything from the training of the soldier to the drill, from underarm to where to live everything had come up. (Berkes, 2014) Finally, Selim III., in 1793, decided to establish an army separate from traditional Ottoman units. The army, called Nizam-ı Cedid, was to be a means of rebuilding the central administration of the state and bringing control of the ayans. (Karpat, 2014)

Nizam-ı Cedid army would use the tools and equipment imported from France. French teachers were to be trained. But because of this pro-French attitude, there was a social opposition to Selim III. Also, the formation of an army attached to him threatened the social status of both janissaries and ayans. To finance the new army, the Treasure of Irad-ı Cedid was established, and taxes were increased. With the new charges, public discontent started to rise. In a short period, the unification of the factions against the center under the leadership of the ulema class became inevitable. Inflation increased due to financial inadequacies. The people of Istanbul started to support the group against Sultan Selim. The faction headed by Grand Vizier Hilmi Paşa and Şeyhülislam Ata'ullah Efendi revolted the Janissaries in 1807 and deposed Selim III. Instead of the III. Selim, they passed IV. Mustafa to the throne. (Inalcık, 2013)

In 1812, Napoleon marched on Russia with his army. II. Mahmud had the opportunity he had been waiting for since the Sened-i Ittifak in 1808. He used the large army under his command as the first thing against the traitors that threatened central power. The struggle against the ayans led to the dissolution of the provincial forces and the shift of power towards the palace. The most significant step for the cleansing of the opposition groups and the most radical military reform was the abolition of the janissary. On June 12, 1826, the janissary battalions were selected as useful to the army, and an army class called the eşkinciyan was established. Those soldiers who agreed to abide by the new rules would be treated well. After the news spread, the rebellion of the janissaries began. II. Mahmud took action with the support of the ulama class against the janissaries with his artillery units and officers. (Mantran, 2012) On June 15, the janissary barracks were held on the cannon, and the part that caused the gangrene effect in the Ottoman Empire was dismantled. To remove the Janissaries and to prevent the reactions from the people, the closure of the Bektashi monasteries was called "Vaka-i Hayriyye" in the words of Es'ad Efendi. (Efendi E. , 1243)

The abolition of janissaries had crucial implications for the economic structure in Bulgaria. For example, the data on the economic situation of the Janissaries in Vidin in the 18th century clearly reveals that most of the janissaries were busy with other things apart from military service to increase their economic income. (Atanasov, 2008) The most important of these results was the central authority vacuum that came with the elimination of an important institution from the classical period of the Ottoman Empire. The gap of this central authority was filled by the ayans and merchants. So what was the theoretical inference? In practice, how 


\section{Articles}

did ayans and merchants come to the fore? What were the reflections from the theoretical window of corporate economics to daily life?

Ayan and prominent families found an unlimited area of freedom, as they provided for political, military, and economic affairs to be carried out on behalf of the state. They played a crucial role in collecting taxes and meeting many needs of the state. (Uzunçarşılı, 2010) The new army needed clothes. To cover the expenses of the new army and the disaster, the state had to generate income. With an elementary logic, the state had to collect taxes to generate revenue. To collect taxes, the economy had to follow a regular course. All of these points can be seen in the traces of an institution that emerged in Bulgaria in the 19th century. That was a bourgeois class. For example, the fabric called aba was sent to Rhodes by sea from Plovdiv, Tatar Pazardzhik, Ahi Chelebi, Daridere, Sliven, Kotel, and Thessaloniki. Aba was coming to Istanbul from Rhodes. Aba, produced raw, was also processed and sold here by entrepreneurs and traders as in the case of pro-industrialization. The state was establishing a kind of commercial partnership with those doing this. Mihalaki Gümüşgerdan was the partner of the state at the beginning of the 19th century. He was also called an abacibasi. Mihalaki Gümüşgerdan provided all the needs of the newly established army. The abolition of janissaries provided a new opportunity for Gümüşgerdan. Thus, he had the chance to have close relations with the state. Mihalaki Gümüşgerdan, of course, was not the only example of the rapprochement of the state with merchants. The Kyrou-Sahtiandzhi family began to operate in the region until the end of the 18th century. In this process of convergence, they started to sell fabrics to Anatolia, the Middle East, and even India with
Ottoman Institutions and Legal Regulations in 19th Century Bulgarian Economy

the support of the state. (Lybertaros, 2012) This was not just a matter of fabric. The variety of products used in trade began to increase. Many entrepreneurial families started to grow by doing business directly with the state (such as Gümüşgerdans, Georgievs, Chalikovs, Aries). The abolition of the Janissaries allowed entrepreneurs to act in more comfortable conditions in the economic field. Not only the Bulgarian merchants but also the European traders who came to the region were able to trade more comfortably in a relatively peaceful environment. The disappearance of the monopolies created by the Janissaries, the end of the bandit movements, the creation of new military mechanisms by the Ottoman Empire to defend those regions, and the act of providing stability helped the economic markets to relax. Agricultural income from the territory of Bulgaria was transferred to trade and an incredible economic breakthrough began. Taking advantage of the fact that the Balkans were very close to Europe, the traders there began to integrate into world trade without pressure and constraints. They began to establish trade colonies in Odessa, Bucharest, Braille, Vienna, and Timişoara. (D.Mishew, 1919) The Janissaries' pressure in the countryside prevented the unification of rural and urban production activities in Bulgaria. However, when this pressure was broken, the urban merchant was able to mobilize the production activities in the countryside. (Lybertaros, 2015) Agricultural lands such as Varna, Kotel, Osmanpazar, and Plovdiv were very fertile. This productivity allowed the accumulation of agricultural wealth. Agricultural vitality in Bulgaria in the 19th century was at a high level. (PyceB, 1996) One of the first wishes of entrepreneurs in the field of agriculture was peace in the cultivated lands. The abolition of the Janissaries also 


\section{Articles}

reduced the pressure on entrepreneurs producing agricultural products.

How could the presence or absence of the Janissary army affect the economic structure in Bulgaria? It is possible to say that this military class had lost its order over the years and had reached a position against the state. This class, which called into question the role of the state in the economic structure, was also referred by banditry activities. However, Mahmud's main plan was to strengthen the central authority and collect tax debts that could not be collected due to janissaries. (Goodwin, 2002) It can be interpreted that the janissaries were an exploitative economic institution for their last period, not for the Ottoman classical period. The disappearance of the Janissary military group was a good development for the Bulgarian merchants. This situation is similar to a sudden sunrise in gloomy and foggy weather. With the Janissaries's disappearance, coordination between the central authority and the merchants increased. As mentioned above, the state had to collect taxes. In doing so, it had the help of the great entrepreneurs in cooperation.

\section{Tax Regulations}

\subsection{Intermediary Institutions}

Collecting taxes by Bulgarian entrepreneurs or voivodes also became one of the significant problems in the economic structure. While examining this problem, it is necessary to consider the ideas of nationalism in the 19th century, together with the criteria of economic poverty. The Bulgarian society in the 19th century did not consist of a single political ideology. Some political ideologies were based on economic concerns, some on religious factors, and some on independence ideas. These different political views should be mentioned.

In the 19th century, four main political thought streams emerged in Bulgaria. These are called Turkophiles, Dualists, Russophiles, and Revolutionaries. The Turkophiles were some of the chorbadjis (It should be noted that some of the chorbadjis were Turkish supporters, while others support the Bulgarian national ideology. It is a biased approach to say that all chorbadjis were Turkophiles) and the top traders and industrialists they did business with, who adopted the Turkish administration and wanted this order to continue. Dualists on; large and middle-class merchants, supporting a monarchy where both the Bulgarians and the Turks would be influential, were craftsmen inside and outside the country. Rusofile on; It was the foreign merchants immigrating from Romania to Bulgaria and the group supporting the Russian intervention. The revolutionaries consisted of artisans and landless peasants who became impoverished as a system protester against Liberal factions, enriched merchants, and industrialists. (Daskalov, 2004) It can also be said that two thoughts appeared among the merchants after the Crimean War. The first is called Olds. Gavril Krüstevich was the leader of this group. He was the representative of the big fabricators and sarrafs who believed that they should trade preserving the old order and getting Russian or Ottoman support. The new ones are smaller tradesmen, traders, and guild masters, those who want to live without being tied to both, and their representatives are Petko Slaveikov. (MacDermott, 1962) The society and merchants who adopted the Bulgarian nationalism, launched a social criticism against the pro-Turkish chorbadjis. The tax collection of chorbadjis from their people made them undesirable. They are 


\section{Articles}

remembered in social memory and culture as exploitative institutions.

This class, which was against the national movement, had previously rebelled and collected taxes on behalf of the Ottoman, also attracted the majority reaction with its assets. The chorbadjis, who played an important role in the Ottoman tax system, first appeared in cities such as Plovdiv, Gabrovo, Tirnova, and Zishtovi. Its commercial connections extended to Ottoman commercial cities such as Izmir, Thessaloniki, and Istanbul, as well as to world trade centers such as Moscow, Vienna, and Petersburg. (Bobcev, 1938) This situation of the chorbadjis was reflected in the novels. The Yordan Diamandieff character in Ivan Vazov's Under the Yoke novel was just like real-life chorbadjis. They were not loved by the comrades, accomplices, and the public of the Turks. They were dressed differently from the Bulgarian shopkeepers and peasants. Most of these people spoke Greek, not Bulgarian, and enjoyed the advantages of Orthodoxy. (Glenny, 2012)

After saying that they are enriched with tax collection, two problems arise here. First, arbitrary practices/abuse by chorbadjis while collecting taxes. The second point is heavy taxes, which play a vital role in the Bulgarian national movement. Heavy burdens will be examined in more detail in the next subtitle. In the iltizam (tax farming) system, an entrepreneur, the owner of the money, is entitled to collect the tax of an area within an annual or three-year or another period, provided him guaranty. In return for this right, the state pays the tender price determined by the state to the Ottoman treasury in cash. They collected taxes during the year. However, those who receive tax farms, mültezims (tax farmers/collectors), collect more taxes to make a profit. The fact that chorbadjis collect taxes
Ottoman Institutions and Legal Regulations in 19th Century Bulgarian Economy

for their wealth from what they should was one of the biggest reasons for the Bulgarian nation to win their hatred. (Georgi Stoikov Rakovski, 1987) The chorbadjis were an example of exploiting institutions in the theory of institutional economics. The exploitation of a particular group and the exclusion of other sections is one of the obstacles to economic development. Chorbadjis also played an exclusionary role during the 19th century by keeping the economic activities in the territory of Bulgaria under their monopoly.

\subsection{Heavy Taxes}

The tax rates applied by the Ottoman Empire in the Balkans in the 1830s were high for the public. Both the high tax base and the exploitation of chorbadjis put severe pressure on the public. In particular, the districts of Niş and its surroundings witnessed the Serbian Revolt and met with nationalist feelings beforehand. Due to the massive tax burdens, minor rebellion movements occurred in these regions. Tax burdens occurred in 1835 in Berkovitsa, in 1836 in Pirot and Berkovitsa. The reason for these three riots was that proTurkish groups collected excessive taxes and the state's tax base was high. (Pinson, 1975)

When the conditions of the Tanzimat Period began to be implemented, the iltizam system was lifted. The method of muhassıllık ( the system based on government officials' tax collection), which was deemed to be more productive, was replaced. However, we see that the tension between government officials and local elements did not decrease. In 1841, 600 local families (peasants) joined the rebellion in the great revolution in Nis. (Pinson, 1975)

The scarcity of labor in Bulgaria in the 19th century was another problem. When the high taxes were added on top of this, the Bulgarian 


\section{Articles}

peasants could not get surplus from the land. The crushing of the villagers under this pressure paved the way for the abandonment of the area by the great farm owners, banditry activities, and rebellion. (MacDermott, 1962)

It is necessary to narrate an anecdote about these high tax rates. The traveler George Keppel, who was in the Ottoman lands in 1829 and 1830, described the dialogue with a Bulgarian dragoman named Mihalaki in Istanbul. Mihalaki told Keppel that the Ottomans and Britain collected the same level of tax, but Britain produced enough for the world, while the Ottomans received the same charge without production. (Keppel, 1831) We can say that the information provided by Keppel is correct. Indeed, we observe that the tax collected by the Ottoman Empire from the Balkan states increased during the 19th century. (McGowan, 1981)

This tax issue had become so annoying that it was even reflected in songs that are an integral part of everyday life. We can see this in the lyrics of the song Mishew quoted on the subject. (D.Mishew, 1919)

"There had assembled, there had come together

Mayors and Chorbadjis,

Right in front of the village square,

The Sultan's taxes to assess;

To many, a man impost was imposed,

To many, a man state dues were incised,

To poor Theodore dear, three hundred was inscribed,

Three hundred with full fifty to boot,

For Theodore was a person rich in land"

Instead of accepting tax rates as if they were a formal institution, an inference can be made as follows. The abnormally high tax rates make exploitative economic structures permanent. Although we cannot treat it directly as an institution, tax regulations are directly related to the welfare level of the public. It plays an important role both in terms of the peace of the people and the promotion of production. If we accept tax regulations as an institution in general terms, it can be said that high tax has a role in building exploiting institutions. On the contrary, a charge at reasonable rates will also activate inclusive institutions.

\section{Law Regulations}

\subsection{Tanzimat Reforms}

The peak of the modernization efforts started by the Ottoman Empire was Tanzimat. The central ideology of Tanzimat was to unite different identities within broad geographical boundaries into one superior identity. This ideology, called Ottomanism, is essential for legal regulations and economic structures. The Tanzimat reforms were thought to consolidate the Ottoman central rule in the Eastern Mediterranean and the Balkans and reinforce the authority of the sultan. (Palmer, 1992).

First of all, for the Tanzimat principles to be successful, the ayan families, the landowners, and the beys who settled in Rumelia and Anatolia had to be eliminated. (Inalcık, 2018) The law was united. Generally speaking, a peasant and a minister living in any location of the empire were considered equal. (Mantran, 2012) Of course, the primary purpose of Tanzimat was to introduce an effective taxation system. The current system of tax collection, the iltizam system, was abolished (It was abolished in regions where the Tanzimat reforms were valid.) (Çakır, 2001) The state's salaried officials were replaced. It was their main task to explain and implement Tanzimat reforms wherever they went, to set up assemblies, to collect taxes, and to check the records of taxpayers' property. State officials and people in the region would be 


\section{Articles}

together in the assemblies to be opened. An efficient and normal taxation process would begin. (Findley, 2012)

State officials and people in the region would be together in the assemblies to be opened. An efficient and normal taxation process would begin. This meant a transition to a direct taxation system. However, it was understood that this system was not useful in the long term. In this system, which was tried in 1840 and 1841, it was understood that the muhassıls abused their duties. (Zürcher, 2013) Since the new system was not very functional, it was soon removed, and tax farming system was put into practice again.

Tanzimat's approach to tax was transparent. Taxes would be equal, fair, and spending controlled. In addition to this purpose, the way he paved the road to ensure the rule of law was more important. References to fundamental rights and freedoms such as the Muslim and non-Muslim equality brought by Tanzimat, the narrowing of the area of sharia played a more inclusive role in the next process. (Tanör, 2016) Steps were taken towards the formation of written legal rules. This made it easier to make decisions that would directly affect economic development in the later process. The enactment of the law that allowed nonMuslim citizens living in the Ottoman territory to own land in 1867 was a product of this process. From this aspect, guaranteeing private property rights and equality between individuals with legal texts plays a vital role in the establishment of inclusive institutions in the economic structure. It can be said that the thought and implementation of the Tanzimat had a positive effect on building inclusive institutions.
Ottoman Institutions and Legal Regulations in 19th Century Bulgarian Economy

\subsection{Regulations of Chorbadjis}

As we mentioned earlier, the chorbadjis was an intermediary institution between the public and the state. They were both politically and economically active in the region. They were responsible for collecting taxes and setting taxes. They were representatives of the Ottoman administration. When this situation combined with heavy tax burdens, public complaints started to increase. After the rebellion that began in Tirnova in 1856, Midhat Pasha was sent here and took some measures. In 1857, a new legal text was issued. According to these laws:

- Chorbadjis could serve for a maximum of 1 year in their locations.

- The person who does chorbadjis for one year will not be a chorbadji for at least two more years.

- The majority of the people will want to see them as chorbadji, and whoever they choose will be those chorbadji.

- No matter what the chorbadjis are, they will not take many taxes from the public and do not put a chore on the audience.

- Chorbadjis will not try to buy agricultural products cheaply from the farmers.

- When any guest arrives, these costs will not be covered by money and food from the public.

- It will record the taxes they collect in the Tırnova Liva Assembly.

- If a chorbadji is accused of corruption or irregularity by the citizens before his term of office expires, and the Tırnova Assembly establishes this fact, he will be put to trial immediately. ${ }^{2}$

Here, it is seen that the Ottoman administration was trying to reduce the

2 Ottoman Archive (Başbakanlık Osmanlı Arşivi, BOA.) BOA. İrade-i Meclis-i Vala (i.MVL.) Kutu: 384, Gömlek: 16793 - (Niş eyaleti ile diğer eyaletlerde bulunan kocabaşıların ıslahatı hususu) Date: H-20-04-1274. 


\section{Articles}

reactions after the public rebellions. The Ottoman did not abolish the chorbadji establishment, but it narrowed its powers. Thus, the aim was to reduce the pressure on the people. However, how functional were these laws in practice, considering the critical position of chorbadjis in tax collection and trade? Thinking as a legal regulation, limiting the power of a particular group, and reducing its capabilities is one of the factors that provide economic development according to the corporate economic theory. Although the declaration of chorbadjis regulation laws does not provide significant improvements in practice, we can say that at least the peace of the people increased.

\subsection{Midhat Paşa's Reforms in Bulgaria}

The Crimean War (1853-56) had created trauma in the Ottoman Empire. The Ottomans, who had to protect their borders, had to deal with nationalist movements as well as their wars with other states. After the Crimean War, the importance given to the Balkans increased. In 1860, Kıbrıslı Mehmet Pasha made a series of observations in the Balkans. (Köksal \& Erkan , 2007)

In 1861, Midhat Pasha was appointed as Nis governor. On 8 November 1864, the regulation called the Tuna Vilayeti Nizamnamesi entered into force. The laws changed the administrative structure of a region. Places formerly called eyalet were now vilayet. The subunits of the vilayet were the sancaks. The lower unit of the sancak was kazas. The subunit of the kazas were the kariye and nahiye. (Davison, 1997)

The arrangements of Midhat Pasha revived the Danube provinces in economic terms. Reforms and regulations in almost all areas increased the commercial capacity of the region. He developed various applications for the evaluation of agricultural capacity. Memleket sandıkları were established. These sandıks were established to support the peasants. The primary purpose was to increase agricultural production by giving agrarian loans in the Danube province. By 1867, the total capital had reached 20 million gurus in these sandıks. (Güran, 2014) Agricultural loan volume of the Ruse province increased from $1,883,000$ cents to $3,665,095$ cents. The place where the increase in agricultural productivity was high, was in Silistra. The system established by Mithat Pasha had increased the agricultural capacity in Silistra. By 1877, the treasury of the country chest in Silistra had reached $3,042,552$ kuruş. (Atanasov, 2017) The implementation of memleket sandıkları was important in terms of revealing the potentials of economic institutions. This means that the arrangements of Midhat Pasha increased the volume of agricultural capital. (Ortaylı, 2011)

It is also imperative for Midhat Pasha to arrange the Danube river transportation. Thanks to the established ferry company, trade on the Danube river was increasing. Both the small industrial class and the peasant class used these infrastructure facilities. Mihtat Pasha built $3000 \mathrm{~km}$ of roads and 1400 bridges in Bulgaria in about four years. These moves improved the infrastructure and industrial capacity of the Danube province. In this way, the income of the Danube province started to increase. In 1856, it reached up to 300,000 pouches $(1$ pouch $=5$ cents). (Ortaylı, 2011)

One of the most critical arrangements was the dominance of the central structure. The effectiveness of ayan and chorbadjis, who played a role in previous processes, was reduced. The administrators elected by the people of the province were coming to the 


\section{Articles}

provincial council. Commissions were also established in all areas. Decisions were taken in these commissions. A lot of books, articles, etc. can be published on the topics covered so far. However, as we mentioned at the beginning, explaining all these facts in detail will exceed the limits of this article. Therefore, the main goal of this article is to make short summaries about institutions and regulations and to discuss how they play a role in the economic development. For this reason, after making an overview of the reforms made by Midhat Pasha, we can say that he established a legal infrastructure that directly affected the economic development positively.

\subsection{Regulation of Lands in $\mathbf{1 8 5 8}$}

Ömer Lütfi Barkan, one of the leading figures in the history of economics, strongly opposes the claim that the Bulgarian Revolt in 1876 took place because the Turks and Muslims had vast, extensive, fertile lands. (Barkan, 1980) The Bulgarian rebellion was not a simple land-sharing. It had economic, social, religious, and cultural effects. There were some changes in the land arrangement of the Ottoman Empire. Tanzimat and the law enacted in 1858 was of great importance in terms of institutional economics on the land issue.

The general purpose of the law was to prevent the collection of state lands and large lands in one hand. For example, the land of an entire village could not belong to one person. Thus the peasants would be protected. (Kenanoğlu, 2006) In addition, with another law enacted in 1867, non-Muslims living in the Ottoman Empire were also given the right to own land. In other words, Ottoman Christians could obtain title deeds and own private property. It is very important for the corporate economy that the state protects
Ottoman Institutions and Legal Regulations in 19th

Century Bulgarian Economy

the peasants and especially guarantees the property right. The effect of this law on the Bulgarian economy is great. The state encourages people to enrich, to transform their savings to investment.

\section{Financial Instruments}

In the 19th century, financial institutions gradually started to form in Bulgaria. The integration of the Bulgarian territory in international trade brought financial institutions with it. Financial development also took place in the vicinity of these people, as both the people called sarraf in the asylum system were guarantors, and they met their cash needs in long-distance trade. In other words, a financial system developed among tax collectors - traders - Armenian or Jewish money - Orthodox elites - Muslim ayans. (Lybertaros, 2010)

We can see that these charges were guaranteed in many tax tenders in the territory of Bulgaria. Again, the need for money was met by these consumers many times while trading. There is a complex hierarchy here. The work of the sarrafs is to lend with interest. However, traders did not have such a function. It was later on that traders started lending money and became financial institutions like bankers. Later, these institutions played an important role in the establishment of banks. According to two critical historians Svetla laneva and Andreas Lybertaros, who worked on these issues, the basis of this monetary system was that the state did not give loans to the peasants. In this case, traders engaged in international trade served as financial institutions by lending money to the villagers and renting money. (laneva, 2011) So what happened to these financial institutions? Why could they not they keep up with the modern system? Hristian Atanasov answers 


\section{Articles}

this question as follows. Sarraf- chorbadji and bureaucrat business cooperation had the functions of financial institutions. However, bureaucrats could not modernize because they had limits. (Atanasov, Credit Institutions in the Bulgarian Lands during the 18th and 19th Centuries. An Attempt for Review, 2018)

Although it cannot turn into a modern banking approach, this financial experience is significant for the Bulgarian economy. In the following years, a modern banking system will be built on this financial experience. However, if it is evaluated according to the institutional economic approach in the 19th century, the financial system was limited. The credit utilization rate was low. That is, the credit system was not widespread among the lower and middle groups. One should not forget the impact of the financial reforms that Mithat Pasha initiated here. Briefly, the existence and development of financial institutions is very important to the economic development according to principles of institutional economics.

\section{Conclusion}

This article aims to analyze the Bulgarian economy in the framework of institutional economics based on the institutions in the 19th century. Based on the institutional economic theory we discussed in the introduction, we examined the effects of some Ottoman institutions on economic development. Accordingly, we identified some institutions and explained whether they were exploitative or inclusive in the Bulgarian economic development. In the first part, we examined the guilds and janissaries among the traditional Ottoman institutions. Although the guilds had exploitative institutions for the 19th century, we found that they were essential for the economic structure in times of crisis. We have said that the removal of the janissaries, which was an exploitative institution, directly affected the economic development in the 19th century. We noted that after the Janissary ended, economic growth also increased. In the second subtitle, we discussed taxes. We have argued that intermediary institutions that play a role in the collection of taxes have an exploitative effect. We have demonstrated that tax burdens were one of the exploiting institutions in the Bulgarian territory under the Ottoman administration. In the third chapter, we considered the legal structure as an institution and looked for the factors that would affect the economic structure in various legal texts. In this subtitle, we supported the Ottoman legal arrangements to create inclusive institutions in the economic structure. In the last part, we briefly touched on the development of financial institutions. We tried to explain the financial system and experiences Bulgaria had when it became an independent state. Given the spontaneous nature of financial institutions, it can be said that they are generally exploitative institutions. Anachronism is another point that should not be forgotten here. The conditions of the 19th century and today are, of course, not the same. Therefore, it is necessary to evaluate the circumstances of that period within itself. Finally, as we said in the introduction, this article is based on the theory of corporate economics to identify a new perspective on the 19th-century Bulgarian economy by identifying inclusive and exploitative institutions.

\section{References}

(Başbakanlık Osmanlı Arşivi, B. İrade-i Meclis-i Vala (I.MVL.) Kutu: 384, Gömlek: 16793 


\section{Articles}

Acemoğlu, D., \& Robinson, J. (2013). Why Nations Fail: The Origins of Power, Prosperity and Poverty. London: Profile Books.

Atanasov, H. (2008). V osmanskaya periferia: obstestvo i ikonomika vav Vidin i okolnostta prez XVIII v. Sofya: Sineva Publishing House (in Bulgarian).

Atanasov, H. (2014). Kam podrejdaneto na puzela: normiranite ceni vav Vidin, Ruse I Sofyia ot sredata na XVII do nachaloto na XIX vek. Istorichesko badeste, 1-2, 3-52 (in Bulgarian).

Atanasov, H. (2017). Razvitie na zemedelskoto kreditirane $v$ Dunavskia vilaet: "Obshtopoleznite" kasi prez 60-te u 70-te godini na XIX vek. Sofya: Faber (in Bulgarian).

Atanasov, H. (2018). Credit Institutions in the Bulgarian Lands during the 18th and 19th Centuries. An Attempt for Review. Proceedings of the Centre for Economic History Research (s. 62-75). Varna: Centre for Economic History Research.

Barkan, Ö. L. (1980). TÜRK TOPRAK HUKUKU TARIHINDE TANZIMAT VE 1274 (1858) TARIHLi ARAZI KANUNNAMESI, Türkiye'de Toprak Meselesi, Toplu Eserler 1,. İstanbul: Gözlem Yayınları.

Berkes, N. (2014). Türkiye'de Çağdaşlaşma. İstanbul: Yapı Kredi Yayınları.

Bobcev, S. (1938). Notes comparées sur les çorbacis chez les peuples balkaniques et enparticulier chez les Bulgares. Revue Internationale des Etudes Balkaniques, 428445.

Çakır, C. (2001). Tanzimat Dönemi Osmanlı Maliyesi. İstanbul: Küre Yayınları.

Commons, J. R. (1925, February). Law and Economics. Yale Law Journal, s. 371-382.
Ottoman Institutions and Legal Regulations in 19th Century Bulgarian Economy

D.Mishew. (1919). The Bulgarian in the Past Pages from the Bulgarian Cultural History. Lousane: Libraire Centrale des Nationales.

Daskalov, R. (2004). The Making of a Nation in the Balkans: Historiography of the Bulgarian Revival: Bulgaria. Budapest: Central European University Press.

Davison, R. (1997). Osmanlı Imparatorluğu'nda Reform. İstanbul: Papirüs.

Efendi, E. (1243). Üssi Zafer. İstanbul.

Efendi, E. (1243). Üssi Zafer. İstanbul.

Findley, C. (2012). Modern Türkiye Tarihi. İstanbul: Timaş Yayınları.

Güran, T. (2014). 19.Yüzyılda Osmanlı Ekonomisi Üzerine Araştırmalar. İstanbul: Türkiye İş Bankası Yayınları.

Genç, M. (2013). Osmanlı Imparatorluğunda Devlet ve Ekonomi. İstanbul: Ötüken Yayınları. Georgi Stoikov Rakovski, ,. (1987). A Great Son of Bulgaria and a great friend of India, Vessely Nikolov and G. Mukharjee. New Delphi: Nothern Book Centre .

Glenny, M. (2012). The Balkans 1804-1912; Nationalism, War and the Great Powers. Toronto: Anansi Publish.

Goodwin, G. (2002). Yeniçeriler. İstanbul: Doğan Kitap.

Hodgson, G. M. (2007). The Evolution of Economic Institutions- A Critical Reader. Eheltenam: Edward Elgar Publishing.

laneva, S. (2011). The non-Muslim Tax Farmers in the Fiscal and Economic System of the Ottoman Empire in the 19th Century. Middle East and Islamic Studies, 45-63.

İnalcık, H. (2013). Devlet-i Aliyye, Osmanlı Imparatorluğu Üzerine Araştırmalar-I. İstanbul: Türkiye İş Bankası Kültür Yayınları. 


\section{Articles}

İnalcık, H. (2013). Osmanlı Imparatorluğu Klasik Çağ (1300-1600). İstanbul: Yapı Kredi Yayınları.

İnalcık, H. (2013). Osmanlı ve Modern Türkiye. İstanbul: Timaş Yayınları.

İnalcık, H. (2018). Tanzimat ve Bulgar Meselesi. İstanbul: Kronik Yayınları.

Köksal, Y., \& Erkan , D. (2007). Sadrazam Kıbrısı Mehmet Emin Paşa'nın Rumeli Teftişi. İstanbul: Boğaziçi Üniveritesi Yayınları.

Kütükoğlu, M. (1983). Osmanlılarda Narh Müessesesi ve 1640 Tarihli Narh Defteri. İstanbul: Enderun Yayınları.

Karpat, K. (2014). Osmanlı Modernleşmesi; Toplum, Kuramsal Değişim ve Nüfus. İstanbul: Timaş Yayınları.

Kenanoğlu, M. (2006). 1858 Arazi Kanunnamesi ve Uygulanması. Türk Hukuk Tarihi Araştımaları , 107-138.

Keppel, G. (1831). Narrative of A Journey Across the Balcan 1829-1830 by the Two Passes of Selimano and Pravadi Also of A Visit to Azami and Other, Newly Discovered Ruins in Asia Mino. Londra: Henry Colburn and Richard Bentley Publishing.

Lybertaros,A. (2010). Men of the sultan: the beğlik Sheep Tax Collection System and the Rise of a Bulgarian National Bourgeoisiei $n$ Nineteenth-century Plovdiv. Turkish Historical Review, 55-85.

Lybertaros, A. (2012). "Çelebis and Guildsmen in pre-Tanzimat Plovdiv: Breaking through the Orthodox Ancien Régime. Political Initiatives From the Bottom Up in the Ottoman Empire, (s. 107-115). Irakleion.

Lybertaros, A. (2015). State and Economy in late Ottoman Thrace; Mihalaki Gümüşgerdan and The Woollens of the State. Turcica, Revue d'études turques, s. 205-236.
Lybertaros, A. (2015). tate and Economy in late Ottoman Thrace; Mihalaki Gümüşgerdan and The Woollens of the State'. Turcica, Revue d'études turques, s. 205-236.

MacDermott, M. (1962). A History of Bulgaria. New York: Frederick A.Praeger Publish.

Mantran, R. (2012). Osmanlı Imparatorluğu Tarihi II Duraklamadan Yıkılışa. İstanbul: Türkiye İş Bankası Yayınları.

Mantran, R. (2012). Osmanlı Imparatorluğu Tarihi-II. İstanbul: Türkiye İş Bankası Yayınları.

McGowan, B. (1981). Economic Life in Ottoman Europe, Taxation, trade and the struggle for land, 1600-1800. Cambrigde : Cambrigde University Press.

North, D. C. (1990). Insitutions, Institutional Change and Economic Performance. Cambridge: Cambridge University Press.

North, D. C. (2005). The Process of Economic Change. Princeton: Princeton University Press.

Ortaylı, i. (2011). Tanzimat Devrinde Osmanlı Mahalli Idareleri (1840-1880). Ankara: Türk Tarih Kurumu Yayınları.

Özyüksel, M. (2007). Feodalite ve Osmanlı Toplumu. İstanbul: Derin Yayınları.

Palmer, A. (1992). Son Üç Yüz Yıl Osmanlı Imparatorluğu. İstanbul: Tükiye iş̧ Bankası Yayınları.

Pamuk, Ş. (2014). Osmanlı-Türkiye iktisadi Tarihi 1500-1914. İstanbul: Iletişim Yayınları.

Penchev, P. (2008). "Polemics about the economic consequences of the Russo-Turkish war of liberation (1877 - 1878). Historical review, vol. 3 - 4, 49 - 74 (in Bulgarian).

Pinson, M. (1975). Ottoman Bulgaria in the First Tanzimat Period - The Revolts in Nish 


\section{Articles}

(1841) and Vidin (1850). Middle Eastern Studies, 103-147.

Polanyi, K. (2001). The Great Transformation The Political and Economic Origins of Our Time. New York: Beacon Press.

Roussev, Iv. (1996). Firmi i manifakturi v Slivensko-Kotlenskia raion prez Vazrajdaneto. Veliko Tırnovo: Faber Publishing (in Bulgarian).

Simon, H. A. (1997). Models of Bounded Rationality Vol.3. London: MIT Press.
Ottoman Institutions and Legal Regulations in 19th Century Bulgarian Economy

Tanör, B. (2016). Osmanlı Türk Anayasal Gelişmeleri. İstanbul: Yapı Kredi Yayınları .

Todorov, N. (2011). 19. Yüzyılın İlk Yarısında Bulgaristan Esnaf Teşkilatında Bazı Karakter Değişmeleri. İstanbul Üniversitesi İktisat Fakütesi Mecmuası, s. 1-36.

Uzunçarşılı, i. H. (2010). Meşhur Rumeli Ayanlarından Türsinikli İsmail, Yılık Oğlu Süleyman Ağalar ve Alemdar Mustafa Paşa. Ankara: Türk Tarih Kurumu.

Zürcher, E. J. (2013). Modernleşen Türkiye'nin Tarihi. İstanbul: İletişim Yayınları. 